\title{
Jurassic animals and algae in the flooring of Our Lady of Sorrows Church in Poznań
}

\author{
MATEUSZ ANTCZAK \\ Adam Mickiewicz University, Faculty of Geographical and Geological Sciences, Institute of Geology, \\ Department of Palaeontology and Stratigraphy, Maków Polnych 16, 61-606 Poznań, Poland; \\ e-mail: mateusz.antczak@amu.edu.pl
}

\begin{abstract}
The flooring of Our Lady of Sorrows Church in Poznan is made of Jurassic rocks from the Świętokrzyskie Mountains (also known as Holy Cross Mountains) and contain abundant marine invertebrate fossils: sponges, bivalves, brachiopods, various families of cephalopods, etc. Some of them can be identified to the genus level. The fossils make it possible to describe the environment and ecosystem of the Jurassic sea and biostratigraphy of the sediment. There are also some significant inorganic structures, which suggest post-diagenetic tectonic movements.
\end{abstract}

Keywords: marine ecosystem, sponges, brachiopods, cephalopods, fossils, invertebrates, limestone, Morawica marble, Bolechowice marble, flooring

\section{INTRODUCTION}

The construction of Our Lady of Sorrows Church ("kościół Matki Boskiej Bolesnej”) in the Lazarz district of the city of Poznan was started in 1900 and ended a year later. The brick church was built in the Neo-Romanesque style and it still is a characteristic point of the district. In 2004, the old tiles were replaced by new flooring made mostly of the so-called "Morawica marble" (Fig. 1) but also of "Bolechowice marble" on the edges. In the flooring, many fossils of marine invertebrates and algae are preserved, including irretrievably extinct groups.

Our Lady of Sorrows Church is not the only, nor even the first, public building where Morawica marble was used in this city (WALENDOwSKI 2008). However, in this church, the tiles cover a large area, with the most abundant, well-preserved fossils, which are easy to observe. Other buildings with this kind of marble in Poznan have fewer fossils in the flooring (e.g. the City Office) or the tiles are much less numerous (e.g. Parish Church, St. Florian's Church) or much older and worn (e.g. Collegium Maius, Queen Mary's Church, Dominican Church).

Although the material of which the flooring is made by stonemasons is called "marble", it is in fact a finely crystalline limestone. Morawica limestones are a mem- 

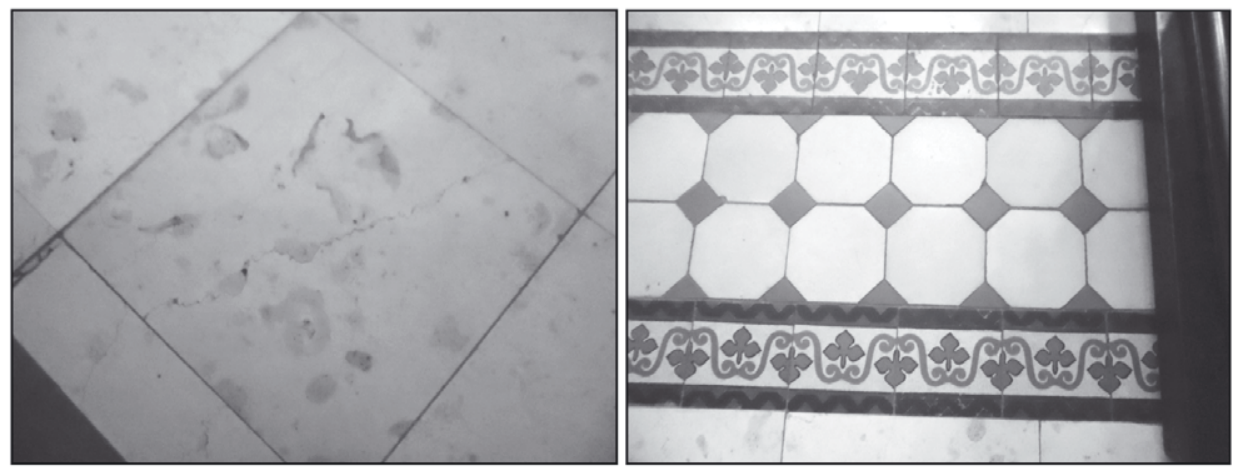

Fig. 1. An old flooring relic and new (since 2004) tiles made of "Morawica marble" in Our Lady of Sorrows Church flooring.

ber overlying Callovian gaizes, marly limestones, grey limestones and underlying the massive limestones and Siedlce limestones (MATYJA 1977) of Jurassic rocks from the south periphery of the Świętokrzyskie Mountains in Poland. Morawica limestones are Upper Jurassic (Oxfordian: 160 Ma) marine sediments with brachiopods, corals, bivalves, gastropods, cephalopods, and echinoderms (RAJCHEL 2001; WALENDOWSKI 2008; ReKovets 2012; KietczewsKa 2013; Kw Morawica 2013).

The aim of this study is to determine if the flooring in Our Lady of Sorrows Church is truly made of Morawica limestones or one of the neighbouring members and if it is possible to reconstruct the whole marine environment based on the flooring.

\section{MATERIAL AND METHODS}

Observations were made during several visits to Our Lady of Sorrows Church in Poznan in 2014 and supplemented with photographic documentation. The church is divided into three naves, which are separated by the rows of benches. In the naves there is no infrastructure that could impede the observations of the flooring and abundant fossils.

Biostratigraphic and palaeoenvironmental interpretation was made using the identified specimens and according to MATYJA (1977) and WRIGHT (1985).

\section{RESULTS AND DISCUSSION}

Most of the groups of fossil animals characteristic of Morawica limestones were found in the church's flooring. Over 200 specimens were recognized, including over 70 ammonites, over 70 belemnites, several dozens of sponges and bivalves, several specimens of algae, and others, excluding equally frequent inorganic structures. In the northern nave, over 30 ammonites and 20 belemnites can be observed. Slightly smaller numbers of them can be found in the southern nave, which instead is charac- 
terized by numerous brachiopod remains. The lowest number of fossils is noted in the central nave, but it is narrower than the two side naves.

Porifera. Based on shape, many poorly outlined fossils can be classified as the remains of sponges, but there are also well-preserved fossils of the Porifera. For example, in the northern nave, in the back (west) of the church, there is a circular cross-section, with a clearly visible osculum (opening of the spongocoel), intake and outlet channels, and pores. Their chain-like distribution suggests that the specimens should be assigned to the family Cnemidiastridae (Fig. 2A).

Brachiopoda. Due to the characteristic shape of the conches, occurrence of the 2 important groups of articulated brachiopods was recorded. Deltoid fossils with a truncate apex belong to the Terebratulida (Fig. 2B, D), and more heart-shaped ones represent the Rhynchonellida (Fig. 2C-D). Both of them are usually approximately $15 \mathrm{~mm}$ wide.

Bivalvia and Gastropoda. Presumable bivalve fossils cannot be classified to lower taxonomic ranks. According to MATYJA (1977), bivalves are frequent in Morawica limestones. Some of the seam-like structures can be remains of the shell ornamentation or commissure of Actinostreon. There are only two probable gastropod fossils in the flooring, but none of them undeniably belongs to the Gastropoda (Fig. 2E).

Cephalopoda: Ammonoidea. Ammonites are abundant and some of the fossils are well-preserved. Internal chambers, including the living chamber, septa and features of the shell can be described. Thanks to this, it is possible to distinguish 3 groups of ammonites. All of them belong to the Ammonitina. The most abundant are evolute shells with many twists and ribs (which is suggested by seam-like shell contour). Those features indicate that such fossils represent the Perisphinctidae (Fig. 2F). Shells with different features are not usually as well-preserved as perisphinctid shells. They have involute an convolute shells with more complex-shaped septa. Some of them belong to the Oppelidae (probably Oppelia or Tarameliceras) (MATYJA 1977) and some are probably representatives of the Haploceratidae (Fig. 2G). These observations are consistent with the biostratigraphy and description of the Ammonitina in the Jurassic rocks from the Świętokrzyskie Mountains. In Morawica beds, the most abundant among ammonites are the Perisphinctdae (88\%), followed by the Haploceratacea ( $8 \%$, represented by the Oppelidae and Haploceratidae), while other groups account for no more than $1 \%$. This contrasts with e.g. the Siedlce limestone, where the Haploceratacea are definitely the most common ammonites $(78 \%)$, or lower marly limestones, where the most abundant are the Aspidoceratidae (38\%) (MATYJA 1977).

Cephalopoda: Coleoidea. Except for the ammonites, the remains of belemnites are the most abundant fossils in the church's floor tiles. The biggest ones are over $15 \mathrm{~cm}$ long. Most of the belemnite remains are relatively small (up to $5 \mathrm{~cm}$ ) and dark cross sections or longitudinal sections of rostra. However, there are also many specimens with details of their internal skeleton (Coleoidea) preserved: the phragmocone divided into chambers, layered structure of the rostrum (composed of alternate layers of $\mathrm{CaCO}_{3}$ and organic substance, conchiolin), and sometimes even the proostracum (rarely present in fossil record), which protects the main mass of the belemnite (Fig. 


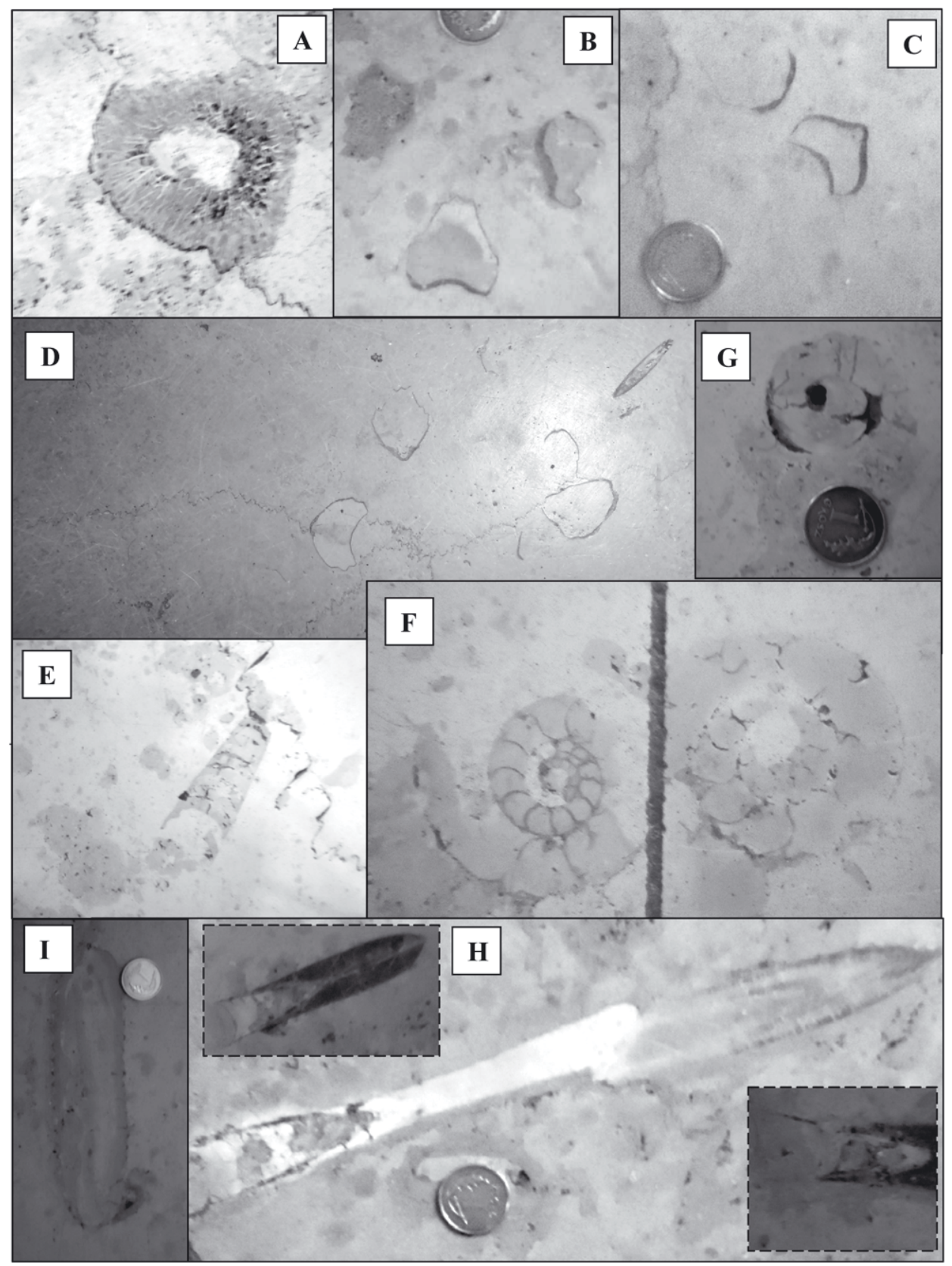

Fig. 2. Fossils from Our Lady of Sorrows Church flooring. A = sponge (Cnemidiastridae); B-D $=$ brachiopods $(\mathrm{B}, \mathrm{D}=$ Terebratulida, $\mathrm{C}, \mathrm{D}-$ Rhynchonellida); $\mathrm{E}=$ gastropod; $\mathrm{F}-\mathrm{G}=$ ammonites ( $\mathrm{F}=$ Perisphinctidae, $\mathrm{G}=$ Oppelidae?); $\mathrm{H}=$ belemnites (Belemnopsis/Hibolites); $\mathrm{I}=$ red algae (Solenopora). 
$2 \mathrm{H})$. The clavate shape of the rostra, distinct enlargement behind the apex, a distinct structure below, and a long explicit alveolus canal, suggest affiliation to the genus Hibolites. The less clavate, more flattened specimens, with an also distinctive and long alveolus, can be classified as Belemnopsis (LeHMANn \& Hillmer 1991).

Rhodophyta. The fossils found in the church include also red algae, Solenopora, which are typical builders of the Jurassic reef and bioherm. They are preserved in the tiles as flattened cross-sections, rectangular with rounded corners (Fig. 2I). According to WRIGHT (1985), the structure of this algal species can reflect seasonal changes in the environment: temperature, insolation, salinity, water circulation or nutrient content. Pink, wider layers are considered as the "summer" layers of rapid growth, while the thinner, beige layers, as "winter" layers of slower or no growth. These are analogical to the changes in extant algae from the order Corallines, which have calcified cell walls.

Others. Massively occurring darker spots on the limestone surface are effects of the calcification of disintegrated sponge skeletons. Among them there are hard to identify ichnofossils and singular echinoderm remains: urchin spines. According to Matyja (1977), some of the poorly-preserved fossils may belong to holothurians and brittle stars.

Environment. The described fossils form an almost complete taphocoenosis, which allows reconstruction of the palaeoenvironment. Domination of the nectonic fauna and benthonic brachiopods and sponges, with a lack of corals (Anthozoa) and rare echinoderms, indicates that the rocks used in the church's flooring originate from an open and relatively deep reservoir, rather than from the coastal zone. Also the occurrence of red algae instead of green algae (Chlorophyta) confirms such conclusions. Almost the whole ecosystem can be described, with autotrophs (red algae), filtrators (sponges, bivalves, brachiopods), and predators that can prey on them (belemnites, ammonites). Only big predators (vertebrates), which can prey on cephalopods, are missing but they are rare in fossil record.

Biostratigraphy. The taxonomic composition of the fossils confirms that the flooring is made of rocks from the Morawica limestone member, but simple observation of the flooring does not allow to describe the species composition and biostratigraphic zones. In the Morawica member, 3 sub-Mediterranean zones can be distinguished based on ammonites, from the lowest: the plicatilis, transversarium and bifurcatus zones (MATYJA 1977). To assign the rocks to one of the zones, more detailed studies are needed.

Inorganic structures. The structures formed after the deposition are also visible. In all the naves there are very abundant and easy to notice stylolites, an effect of stress caused by the upper layers of rocks. These laterally expanded planar features (HeAp et al. 2013) in the flooring can be observed in cross-sections as distinct, wavy and serrated lines across the tiles (WALENDOWSKI 2008). There are at least 2 generations of the stylolites, because one structure is often crossed by another, under the same angle in every tile. This suggests 2 directions of stress, which resulted in 2 generations of stylolites (Fig. 3).

Devonian fossils. On the edges of "Morawica marble" flooring, rows of dark, black-brown tiles with white mineral veins are used. It is also limestone, but in con- 


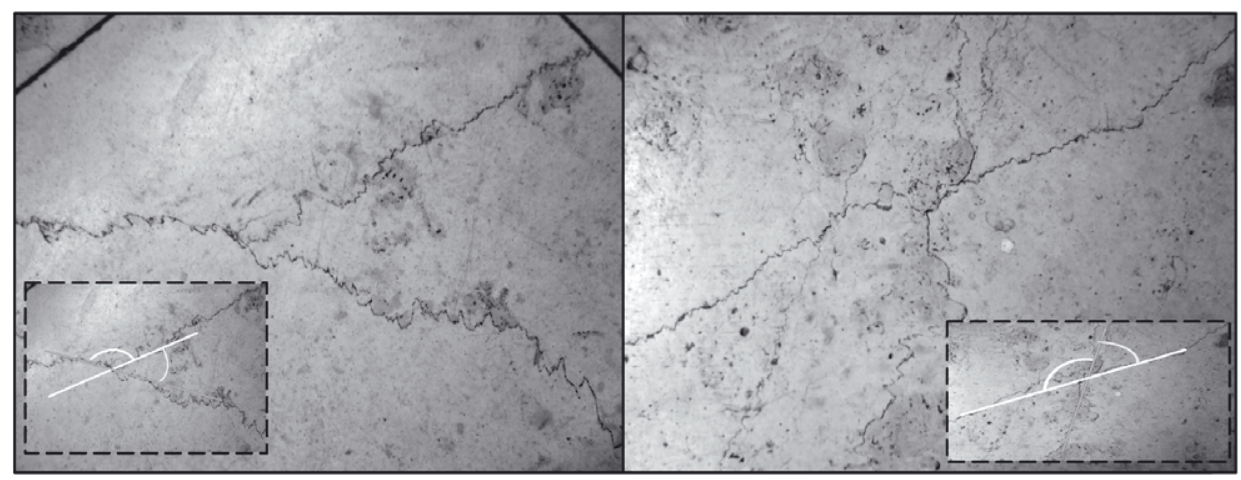

Fig. 3. Two generations of stylolites in Our Lady of Sorrows Church flooring.

trast to the Jurassic "Morawica marble" it is a Devonian deposit, called "Bolechowice marble" (ToŁkANOwicz 2001; KieŁCZEWSKa 2013). Another difference is that its fossils derive from shallow waters. In the dark tiles, representatives of Stromatoporidea can be observed in cross sections: twig-like Amphipora, massive Stromatoporoidea, and solitary corals from the order Rugosa.

\section{CONCLUSIONS}

Observations of the "Morawica marble" (limestone) in Our Lady of Sorrows Church in Poznań allow reconstruction of the palaeoenvironment of the Jurassic (Oxfordian) sea. The almost complete biocoenosis (except some vertebrate predators) of a rather deep water body consists of sponges, brachiopods, ammonites, belemnites, urchins, red algae, and possibly bivalves and gastropods. The structure of the red algae suggests some seasonal changes of the environment (e.g. temperature or salinity). Although "Morawica marble" is used also in other buildings in Poznań, Our Lady of Sorrows Church is the best for palaeoecological research, as numerous wellpreserved fossils can be recognized there.

Acknowledgements: I would like to thank Dr Paweł Wolniewicz for consultations about the floorings in Poznań, for suggestions about important publications and for reviewing the manuscript.

\section{REFERENCES}

Heap M. J., Baud P., Reuschlé T., Meredth P. G. 2013. Stylolites in limestones: barriers to fluid flow? Geology. 42: 51-54.

KIEŁCZEWSKA J. 2013. Świętokrzyskie marmury i wapienie - mały przewodnik po polskich zabytkach, cz. I. [Świętokrzyskie Mts marbles and limestones - a little guide to Polish monuments]. 
Surowce-naturalne.pl, access: 31.12.2014 (in Polish).

Kw Morawica. 2013. Okładziny z kamienia i konglomeratu [Claddings of stone and conglomerate]. Katalog inżyniera [Engineer Catalogue]. 2013/2014: 116 (in Polish).

Matyja B. A. 1977. The Oxfordian in the south-western margin of the Holy Cross Mts. Acta Geol. Pol. 21: 41-64.

RaJChel J. 2001. Kamienie dekoracyjne w gmachu A-0 AGH [Decorative stones in the building A-0 of AGH]. Biuletyn Informacyjny Pracowników AGH [AGH Employee Newsletter]. 96: 17 (in Polish).

ReKovets L. 2012. Jakie tajemnice skrywają nowe podłogi gmachu głównego? [What secrets are hidden in the new floorings of the main building?]. Głos Uczelni WUP [The Voice of the University]. 207: 58-60 (in Polish).

ToŁkanowicz E. 2001. Marmury Polskie [Polish marbles]. Świat Kamienia [The World of Stone]. 4 (in Polish).

Lehmann U., Hillmer. G. 1991. Bezkręgowce kopalne [Fossil invertebrates]. Wyd. Geologiczne, Warszawa (in Polish).

Walendowski H. 2008. Wapień z Morawicy [Morawica limestone]. Nowy Kamieniarz [New Mason]. 32 I 3: 82 (in Polish).

Wright V. P. 1985. Seasonal banding in the alga Solenopora jurassica from the middle Jurassic of Gloucestereshire, England. J. Paleontol. 59: 721-732. 